\title{
Main Factors of Economic Growth of China
}

\author{
V.V. Moiseev \\ Belgorod State Technological University named after V.G. \\ Shukhov \\ Belgorod, 308012, Russia \\ din_prof@mail.ru
}

\author{
E.A. Karelina \\ Moscow State University of Technology \\ Moscow, 127055, Russia \\ opferpriesterin@mail.ru
}

\begin{abstract}
O. A. Sudorgin
Moscow State University of Humanities and Economics 49 Losinistrovskaya St., Moscow, 107150, Russia, sudorginoleg@yandex.ru
\end{abstract}

\author{
S.N. Glagolev \\ Belgorod State Technological University named after V.G. Shukhov \\ Belgorod, 308012, Russia \\ rector@intbel.ru
}

\begin{abstract}
The relevance of the study is due to the importance of China as one of the main leaders of world social and economic development. China's economy has been developing for the last four decades in a row (1978-2018) almost without crises, at high rates, sometimes adding $10 \%$ a year [8]. Today, China is the leading economic power, its gross domestic product (GDP) increased from $\$ 255.7$ billion in 1979 to $\$ 13,05$ trillion in 2018, i.e. more than 50 times [10]. The authors not only reveal the factors of the Chinese phenomenon, but also attempt to analyze the main components of China's success in economic development. The article considers the key aspects of Chinese reforms, analyzes strategic directions of modernization of China's national economy based on strengthening liberalization of the country's foreign economic activity as one of the main conditions for further large-scale borrowing of advanced technological experience of the highly developed countries of the world. A separate place is given to the consideration of the program of socialist modernization, conducted by Deng Xiaoping.

The purpose of this study is a comprehensive analysis of features of China's economic development strategy and the main factors of its rapid growth.

In the article the authors examine the key features of China's economic development strategy, the priority directions of its modernization: public administration reforms aimed at the priority development of the economy and social sphere; they also analyze the features of attracting national and foreign investments for a breakthrough in socio-economic development.
\end{abstract}

Keywords - China; economy; factors; reforms

\section{INTRODUCTION}

The founder of economic reform in China is Deng Xiaoping. While developing the program modernization, Deng Xiaoping did not have ready answers to the most complicated questions of its implementation in a huge country like China. The development of this program was carried out by the method of "crossing the river, groping stones." This slogan is used in China as a synonym for a cautious approach to solving economic problems [21, p. 191]

First of all, the restructuring carried out on his initiative in China presupposed the reform of the economic structure of society with a gradual transition to a market economy. The political life of the country was built in accordance with the "four basic principles": to follow the socialist path, adhere to the dictatorship of the proletariat, the leadership of the Communist Party of China, and the ideas of MarxismLeninism and Mao Zedong in order to ensure the main internal condition of the normal course of reforms-political stability. No deviations from this line towards politico-ideological liberalization were allowed [24]

The supreme Chinese government, acting with its inherent wisdom, abandoned the simultaneous liberalization of prices and the comprehensive privatization of the public sector of the economy, thereby acknowledging the method of "shock therapy" used by President B. Yeltsin as erroneous.

Thus, the transformations in the vast country began with well-thought out and verified reforms, the author of which was Deng Xiaoping, the state, military and party leader of China, who, after the death of Mao Zedong in 1976, was the most influential figure in the Chinese leadership.

Deng Xiaoping's reforms were successfully continued by his successors - Jiang Zemin (1989-2002), Hu Jintao (20022012) and Xi Zemin (from 2012 to the present) [18, p. 14].

Thanks to their well-coordinated work on managing the country's social and economic development, the steady implementation of the course developed by Deng Xiaoping, as early as 2010 the Chinese economy outperformed the Japanese economy and became the world's second economy by nominal GDP, and since December 2014 is the world's first GDP in parity purchasing power. 
A key feature of China's economic development strategy was the building of market relations under the leadership of the Communist Party on the basis of five-year plans, almost like in the Soviet Union during its heyday. Like the USSR, China has achieved impressive results.

Thanks to the reforms initiated by Deng Xiaoping, China has made an unprecedented leap forward in the development of the economy and bringing the Chinese society to the level of "average prosperity", gaining a strong status as one of the strongest countries in the world economy [21, p. p. 193]. At the same time, the uniqueness of the model of China's socioeconomic development lies in the fact that the development of the country's economy in recent years has occurred on the basis of using a combination of state planning mechanisms and market regulation.

In this way, specific implementation of the model of China's socioeconomic development in the last four decades led to steady economic growth, which allows us to be confident with the official forecasts o f China that it will have achieved absolute leadership in the world economy by 2050 .

\section{Problem Statement}

One of the main issues of this study was the issue of the effectiveness of state management of China's economy and social sphere.

The USSR on the eve of its disintegration (1990) produced goods and services for $\$ 404.5$ billion, that is, more than then in China In just 10 years, in 2000, when Vladimir Putin was elected the second president of Russia, China's GDP was already 1192.8 billion dollars, which is three times more than the GDP in our country [18, p.12-14]. After 17 years, the ratio of the economies of the two countries has changed even more and again in favor of capitalist Russia. In 2017, China's economy produced goods and services for almost 12 trillion which exceeds more than 9 times that of modern Russia. China's gross domestic product became the second in the world in nominal GDP, lagging behind the United States only [8].

The conclusion from this brief analysis is that the economic strategy adopted and implemented in China proved to be more effective than the state management of the economy in Russia. Thanks to their well-coordinated work on managing the country's social and economic development, continuity and consistency in achieving the goals, China's economy developed almost without crises at a high rate, which can not be said of Russia, which is positioning itself as a world economic power. However, a special path of socio-economic development in Russia has not justified itself, unlike China.

Reforming the Chinese economy gradually led to structural changes in the location of industry and other sectors of the economy, and then to the rapid growth of nominal GDP. It should be pointed out that, among other branches of China's economy, engineering and metallurgy had the highest priority. Enterprises of heavy industry remain state property. Key industries also include arms production and light industry.

As a result of the implemented reforms in the economy, production at enterprises supported by local authorities (especially in villages and small towns), as well as in enterprises with participation of foreign capital, has seriously increased. By the beginning of the XXI century there were already 7.9 million industrial enterprises in the country, while full employment in state enterprises exceeded 24 million people [7]. The petrochemical and automotive industries have grown substantially in recent years. The main export industries were electronic products and engineering products. The construction sector has also grown substantially.

One of the priority places in the national economy of China is the textile industry, which occupies a leading position in the world, as well as electronics and IT-technologies. For example, while in Russia investments in oil and gas production and transportation get a return in 12 years, the Chinese investments in electronics pay their costs four times within the same period.

An important place in the structure of China's modern industry belongs to the automotive industry. China is the undisputed leader in the production of both passenger cars (22.2 million units in 2017 or $34.5 \%$ of world output) and cargo cars (6.8 million units in 2017 or $22 \%$ of world production). The total production of cars in the country amounted to 29.0 million (29.9\% of world production) in 2017. In 1975-2017, according to the calculations of the authors, car production in the country grew 175 times [9]. Already in 2010, the country took the leading position in the world automotive industry.

China has made significant progress in the development of national energy. With the adoption of a set of measures to rationalize energy consumption in the 1980s, the structure of energy consumption in the country was substantially adjusted. A number of energy-saving measures were implemented (closure of obsolete production, attraction of the latest technologies and foreign enterprises to the country), which allowed to reduce the total energy consumption in the country by $40 \%$.

Thanks to these and other measures to modernize industries, in 2018 China's industrial production for the first time exceeded 30 trillion yean (about \$ 4.4 trillion) [10].

One of the most important branches of the country's economy continues to be agriculture, although its share in GDP declined in 1981-2015 from 21.8 to $9.2 \%$. In 2010, a record grain harvest (550 million tons) was recorded in the country. In Russia, a similar record was set in 2017 - 132 million tons [18, p.14]. To stabilize the growth of prices for agricultural products in the country, the Ministry of Agriculture continues to provide assistance to rural areas in the production of pork, oilseeds, grains and other goods.

The development of transport and infrastructure in China is given significant attention, since these industries are strategically "tied" to the national economy. Annual investments in the development of transport and infrastructure are about $10 \%$ of GDP.

In the social sphere, there have also been significant changes for the better: the employment of the urban and rural population has increased, its incomes have risen, the criteria for the subsistence level and support for the poor in the city and village have increased, the level of social, medical and pensions has been raised (a free education has been introduced 
everywhere and a new system of social assistance, including old-age).

At the XVIII Congress of the Communist Party of China (2012), it was noted that the construction of a "moderately prosperous society" implies progress towards a society of general welfare, viewed as the "basic principle" of socialism with Chinese characteristics. The implementation of this principle is associated with the preservation of the socialist economic system and the distribution system, the ordering of the distribution of citizens' incomes and the solution of the problem of income disparity so that "the results of development are more equitably distributed among the entire population." The report of the Secretary-General of the CPC Central Committee, Hu Jintao [26], stated that it has not yet been possible to overcome the uneven development in the country, especially between town and country, problems in the field of employment, social security, income distribution, education and health, housing, the safety of drugs and products, ecology, justice and public order are identified.

In March 2014, the State Council of China presented the National New-Type Urbanization Plan for 2014-2020, which focused on the quality of growth and well-being of urban residents.

The reforms that promote China's growth in modern conditions are continuing. This was confirmed by the regular plenum of the Central Committee of the CPC, which took place on 26 February $\neg 28$ February 2018 and the 1st session of the All-China Committee of the People's Political Consultative Council of China (CPPCC) of the 13th convocation. "We are entering a new era, and the CPPCC will constantly open new pages in history, more and more closely interacting with the Central Committee of the Communist Party of China"[12].

The main function of the CPPCC is to conduct political consultations, monitor the implementation of key government programs approved by the CPC Central Committee and other state bodies of the People's Republic of China, implement fiscal projects, formulate and discuss key issues of national importance in the field of national politics, economy, culture and social development. The March (2018) session of the CPPCC is of great importance for mobilizing the party and the entire population of China to transfer the ideas of a "decisive victory in the full construction of a moderately prosperous society" and the achievement of the "great victory of socialism with Chinese characteristics" into a new era.

At the June 14, 2018 meeting of the State Council of the PRC, topical problems of the country's socio-economic development under new geopolitical conditions were considered, measures were taken to expand imports that would facilitate the restructuring of the industrial structure and a balanced development of foreign trade, and would also bring more benefits to the population of the country. It was noted at the meeting that the goals of import expansion with the stabilization of exports are to promote the implementation of an openness strategy characterized by mutual benefits and common gains, protecting free trade, transforming and modernizing domestic industry, and satisfying the diverse needs of citizens.
The State Council of the People's Republic of China decided to support the import of consumer goods for domestic needs, medicines, rehabilitation equipment and equipment for elderly care and ensure implementation of measures to reduce import duties on part of the goods; the importance of the allround development of trade in new services and the promotion of the import of manufacturing services, covering research and development, logistics, consulting services, energy conservation and environmental protection, was pointed out; stressed the need to increase the import of equipment that facilitates the transformation and modernization of the country's production. Premier Li Keqiang said that China would actively increase imports and reduce import duties on cars, part of consumer goods for domestic needs and other goods. "We are ready to give greater openness to the Chinese market in order to stimulate the modernization of production facilities, ensure a balanced development of trade, and thereby give consumers more options," he said. [22].

One of the consequences of China's accession to the WTO was a sharp increase in the number of agreements on foreign direct investment. Already in the first year after accession, the volume of commitments for new investments increased by more than a third, and the cumulative influx of foreign investment reached $\$ 350$ billion, with an annual increase of $\$ 40$ billion [13]. Despite the fact that the role of foreign investment in the country is high, almost $80 \%$ of all foreign direct investment in the economy is the investment of ethnic Chinese (huaqiao) - who live abroad.

Great importance in the development of the country's economy and attracting foreign investment was the development of free economic zones (FEZ).

In the next decade, the projected volume of China's direct investment abroad will be $\$ 1.25$ trillion. China's investment abroad helps national companies from different industries to conquer new markets, acquire the necessary managerial experience, technologies, brands, human capital to become more competitive.

\section{RESEARCH QUESTIONS}

The authors examine the key features of China's economic development strategy, the priority directions of its modernization: public administration reforms aimed at the priority development of the economy and social sphere, state regulation of the economy, its diversification, analyze the features of attracting national and foreign investments for a breakthrough in socio-economic development.

Mentioning these and other issues, the authors compare them with the strategic goals and objectives of the development of the Russian Federation for the period until 2024, set out in the presidential decree of May 7, 2018.

\section{Purpose OF STUdY}

The purpose of this study is a comprehensive analysis of key features of China's economic development strategy.

\section{RESEARCH METHODS}

In the article, the authors used the analytical, comparative and institutional methods. The study also used the methods of 
analysis and synthesis, statistical and other methods for determining the current trends in the economic development of China's.

\section{FINDINGS}

As conclusions, the following should be noted.

1. Since the beginning of the policy of reform and opening up, China has achieved impressive successes. The economic reform began with agriculture, followed by the reform of the financial system, liberalization of prices, increased autonomy of state-owned companies, an extensive banking system, stock markets, increased share of the private sector, increased openness towards foreign investment and foreign trade.

Under the conditions of liberalization of foreign economic activity, the transformation of the model of China's investment cooperation with foreign countries has a significant impact on the evolution and state of trade and economic cooperation between USA and China, Russia and China etc.

2. Since the late 70 s of the last century, China has reoriented from a closed, centrally planned economy to an economy oriented toward the development of market relations. The accession of China to the WTO in 2001 contributed to the active expansion of its participation in international trade, especially in 2002-2008. In the Asian region, China became the leader of foreign trade in 2004, ahead of Japan. In 2007, China outperformed the United States, and in 2009 - Germany, becoming the world export leader.

3. Restructuring the economy and increasing the efficiency of using the demographic potential led to more GDP growth. The value of output of industry and agriculture (in US dollar terms) exceeded similar indicators of the United States.

4. In order to stimulate structural changes in the economy, China is actively developing the education system, it organizes the training of its students at the expense of the state in foreign countries (especially in Japan and the USA), stimulates the import of technologies for the development of such progressive sectors as information and telecommunication technologies, biotechnology.

5. Huge socio-economic transformations were carried out in a short historical period. Therefore, China is an example for developing countries.

\section{CONCLUSION}

In conclusion, the authors express the opinion that the key features of China's economic development are the modernization of the economy on a market basis with state control in the social sphere and the high resource potential of China.

The development of the economy in China, the United States, Russia, India, Malaysia, Singapore and other countries of the world depends critically on the effectiveness of public administration. In fact, the leadership of the Communist Party of China in practice has shown that market relations can and should be applied for the country's sustainable social and economic development. At the same time, an indispensable condition should be a sound economic strategy based not on a raw material, as it is in Russia, but on innovative ways of development, as well as steady implementation of the plans.

The example of China clearly shows that even in the absence of the necessary natural resources (for example, oil is supplied to China from Russia, Brazil, Oman, Venezuela and etc.), almost one and a half billion people can make an unprecedented leap in the development of the country provided effective state leadership.

The high growth rates of the economic potential of the People's Republic of China are ensured as a combination of modernization of the economy on a market basis with state control in the social sphere, which ensures internal stability of development, and the availability of high resource potential of China.

As a result of successful reforms, today China is the leading economic power that has a huge scientific and technological potential, as well as nuclear weapons and a multimillion army. Modern China is the world's largest producer of the absolute majority of industrial products: cars, televisions, radios, mobile phones, watches, cameras, washing and sewing machines, bicycles and motorcycles, cotton and silk fabrics, shoes and so on.

In the long term, the emphasis in the transformation of China's social and economic development strategy will be put on the completion of diversified industrialization, the full development of the field of information and communication technologies; a tenfold increase in GDP per capita. A new stage of development based on knowledge and the transformation of the high-tech industry into a key economic sector will be reached; completion of the construction of a "socialist economy with Chinese characteristics" will happen and so will the creation of mature economic institutions.

Even the United States of America, the founder of a unipolar world, is forced to reckon with China today which has a highly developed military-industrial potential.

\section{REFERENCES}

[1] M. Alekseev. Comparative analysis of the development of Russia, the USA, Europe and China // EKO, Novosibirsk, vol. 6. pp. 113-122.

[2] Z. Sh. Babaeva. China's economic development: benchmarks and ways to achieve // Economy and Entrepreneurship, vol. 3 (56-2), part 2, pp.81-84.

[3] Z. Sh. Babaeva. Innovations: the driving force of economic growth in China // Economy and Entrepreneurship, vol. 3 (56-2), part 2. - Pp.9397.

[4] Changes in 40 years in China in numbers. - Retrieved from: http://russian. mofcom.gov.cn/article/counselorsreport/201812/2018120 2821845.shtml.

[5] Ji. Chen. China's economy. Analysis of the state and development prospects. Per. with whale. M.,: Science, $376 \mathrm{p}$.

[6] Q. Chen. The state in the innovation economy of China. Bryansk: Delta, $161 \mathrm{p}$.

[7] China Economic Outlook. - Retrieved from: http://webcache googleusercontent.com/ search? Q = cache; China Statistical Year Book, Beijing: China Statistical Press.

[8] China's GDP grew by 15 times in 30 years. - Retrieved from: http:// russian.people.com.cn/31518/6555668. 
[9] Chinese Automobile Miracle. - Retrieved from: http://expert. ru/ magazine_auto /2007/07 / kitayskoe_avtomobilnoe_chudo.

[10] China's GDP growth and industrial production exceeded 6\% in 2018. Retrieved from: https://www.vestifinance.ru/ articles/113978.

[11] L.E. Grinin. The Chinese model and the prospects for the leadership of China in the world // Where the age of globalization is heading. Volgograd, pp.378-394.

[12] In China, the session of the main advisory body was completed. Retrieved from: https://ria.ru/world/20180315/ 1516398351.html.

[13] China's economy. China in foreign trade. - Retrieved from: http://www.ereport.ru/articles/weconomy/china3.htm.

[14] Ya. Juan. Capitalism in Chinese. State and business: Trans. from English - 2nd ed. Moscow: Alpina Publisher: Moscow School of Management, $374 \mathrm{p}$.

[15] E.A. Karelina. Economy of China in the system of modern world economic relations in the light of the prospects for the development of Chinese-Russian economic relations // Economy and Entrepreneurship, vol. 3 (56-2), part 2, pp.41-43.

[16] E.A. Karelina. Features of the socio-economic development of the PRC in the twentieth century // Bulletin of the Institute of Economics RAS, vol. 2, pp. 162-166.

[17] Lee Sin. (2013).The triangle "China - Russia - USA" in modern conditions // Russia and modern. World, vol. 4, pp.103-108.

[18] V.V. Moiseev. Why Russia can not yet become a prosperous country. M., Berlin, 681 p.
[19] V.V. Moiseev. State policy of economic development of modern Russia: monograph. - M., Berlin: Direct Media, - 349 p.

[20] V.Ya. Portyakov. On the issue of the complex power of China: approaches to the assessment, structure, dynamics, prospects // China in world and regional politics: Past and Present. M., pp.6-21.

[21] DB-O. Regzenova. The basic principles and essence of the reforms of Deng Xiaoping. - Retrieved from: https:// cyberleninka.ru/ article/v/osnovnye-printsipy-i-suschnost-reform-den-syaopina/

[22] Samit SCO in Qingdao. - Retrieved from: http://russian.people. com.cn/n3/2018/0615/c31521-9471752.html.

[23] S.L. Sazonov. The role of transport in the development of China //Asia and Africa today, vol. 1, pp.20-24.

[24] D. Smirnov. Deng Xiaoping and the modernization of China. Problems of the Far East, vol. 5, pp. 21-29.

[25] V.V. Moiseev, V. F. Nitsevich, O. A. Sudorgin. To the question of effectiveness of government management. European Proceedings of Social and Behavioural Sciences, vol. 35, pp. 933-944.

[26] XVIII Congress of the CPC on the tasks of building a moderately prosperous society. - Retrieved from: http://mir-politika.ru/3319-xviiisezd-p-o-zadachah-postroeniya-srednezazhitochnogo-obschestva.html.

[27] C. Zeng. The use of public-private partnership in construction in the People's Republic of China // Zhurn. legal and economic research Gatchina, vol. 1, pp.104-108. 